\title{
Class Cultures, Resistance, and the Black Working Class
}

\author{
Fitzhugh Brundage
}

Race Rebels, in myriad ways, brings to mind C. L. R. James' remarkable study of cricket in the West Indies, Beyond a Boundary. Both works are bold yet nuanced, engaged yet measured, sweeping in implication yet focused in scope. Both works revel in the complexity and richness of the culture of marginalized peoples. And both Kelley and James fix their gaze on the rebellious inventiveness of hard-pressed peoples who have struggled to assert control over their destinies. Countless scholars have tried to "empower" and to restore the agency of history's downtrodden, but very few have done it as successfully as James and Kelley.

In focus and method, Race Rebels reflects the ongoing convergence of labor history and cultural studies. Like George Lipsitz, Lizabeth Cohen, and others, Kelley insists that working class culture is as central to the history of the working class as unions and formal organizations. ${ }^{1}$ Kelley joins them in replacing the narrow

1 Lizabeth Cohen, Making a New Deal: Industrial Workers in Chicago, 1919-1939 (New York 1990); George Lipsitz, A Life in the Struggle: Ivory Perry and the Culture of Oppression (Philadelphia 1988); and idem, $A$ Rainbow at Midnight: Labor and Culture in the 1940s (Urbana 1994). 
idea of class consciousness with the much broader notion of class culture. Indeed, he is especially interested in marginalized people who were likely to be on the sidelines of movements or excluded from mainstream organizations entirely. Kelley is not the first scholar to demonstrate the value of this approach for an understanding of the African-American working class, but he is, in my opinion, one of its most skilled and interesting exponents. Despite his debt to contemporary cultural studies, Kelley still deftly grounds his essays in the material conditions of African Americans and retains a deep respect for the importance and potential of radical politics. This balance enables these essays to engage both enthusiastic champions of cultural studies and scholars of the working classes concerned about history's "descent into discourse." 2

Kelley recasts the familiar landscape of both African American and labor history by placing resistance at the center of that history. A generation of historians have been compiling the record of both African American and working class resistance. But after drinking deeply the draught of Gramscian Marxism, especially Gramsci's concept of hegemony, many scholars have doubted the viability and effectiveness of most expressions of counter hegemonic resistance. Consequently, many earlier accounts of resistance took on the quality of a deux ex machina; the dissent was noted and saluted but then the inevitable reassertion of elite hegemony was charted. Race Rebels provides both a subtle exploration of the opportunities for challenges to economic and cultural hegemony in modern America, and compelling evidence of the effectiveness of some of those challenges.

Kelley's inclusive definition of resistance owes an obvious debt to scholars of the Third World, especially to James Scott and to the

2 Bryan D. Palmer, Descent into Discourse: the Reification of Language and the Writing of Social History (Philadelphia 1990). 
school of subaltern studies. ${ }^{3}$ From these sources Kelley has acquired an anthropologist's sensitivity to both the myriad expressions and locations of resistance. Sprinkled throughout the essays, for instance, are interesting observations about the politics of black dress at work and at play. (I hope these essays inspire historians to explore at length the politics of dress at all levels of American society.) The refusal of black household workers to wear uniforms(29) and the penchant of black shoppers to "dress up" when promenading in the black business districts of Atlanta(50) are just two examples of black assertions of dignity through dress. Even more conspicuous was the resistance manifest when a black communist strolled the streets of Chicago in a Russian blouse(108) or when Malcolm Little(X) donned a zoot suit. Indeed, Kelley's decoding of the significance of zoot suits is a brilliant analysis of the use of dress to define and signify an oppositional subculture.(166-7) Kelley's aim in his discussion of dress is to demonstrate that something resembling class struggle can take place without explicit class ideologies, without collective action, even without well defined classes.

Kelley likewise explains the central importance of space in shaping the form and content of black resistance. Just as racial, gender, and class identities encoded dress, so too did they give meaning to space. Any understanding of black resistance must take into account the opportunities and limitations that different spaces imposed upon black expression. Some forms of protest, for instance, were appropriate to the workplace where blacks exploited work traditions and unions to advance their goals. But in other public spaces black dissent required different tactics. As Kelley explains in his account of black resistance in public spaces in

3 James C. Scott, Weapons of the Weak: Everyday Forms of Peasant Resistance (New Haven 1985); and idem, Domination and the Arts of Resistance: Hidden Transcripts (New Haven 1990). On subaltern studies, see Rosalind O'Hanlon, "Recovering the Subject: Subaltern Studies and Histories of Resistance in Colonial South Asia," Modern Asian Studies 22 (February 1988), 189-224. 
Birmingham during W.W.II, the daily humiliations of segregation and racial abuse bore down especially heavily on certain portions of the black community, above all working class women. The repression that blacks encountered on public transportation exacerbated black frustrations but the anonymity of that same public space simultaneously encouraged unorganized resistance. Consequently, the buses of Birmingham became the sites of recurring skirmishes between black riders intent on testing white resolve and white authorities determined to reassert white racial prerogatives.

When the full tradition of black resistance is unveiled, the complexities of power relations in the Jim Crow South and of the struggle by blacks to place limits on white domination also will appear more clearly. Kelley's essays avoid the assumption that white dominance preceded black resistance. White supremacy was not a given; rather, it was something continuously struggled for in an ongoing process of subordination. White domination did not spring fully formed into being to be followed by black resistance. Nor did black resistance operate merely within confines predetermined by white domination. Just as black resistance was constructed and refracted through practice, so too was white domination and its mystifying conceits constantly contested and reasserted. Thus, white domination and black resistance had contemporaneous origins; even while white power worked to condition and mediate black resistance, black dissent in turn fractured and constrained white power. Blacks and whites were bound together in a ceaseless struggle of whites seeking to maintain and extend their domination and of blacks endeavoring to devise strategies to deny and thwart that domination. By taking into account this ongoing contest, and the role of black resistance in it, Kelley replaces the image of the cowed black masses with a more nuanced portrait of an oppressed people who creatively experimented with all manner of dissent, from furtive to public. Rather than concentrating solely on the familiar arena of public protest, Kelley explores the full spectrum of black resistance. Moreover, he goes beyond recording instances of black resistance and begins to ex- 
plain why resistance took one form rather than another, why in one place rather than another, and why then rather than earlier or later.

Kelley avoids any simplistic reading of African American resistance. He is sensitive to its limits, compromises and contradictions. For instance, he contends that the raucous world of black dance halls, blues clubs, and house parties undermined work discipline and challenged middle class propriety. In these spaces, blacks asserted their right to leisure and pleasure. Kelley might have concluded his analysis there. But he readily acknowledges that however much some black clubs were sites of resistance, they also were sites of exploitation for some black workers, especially black women. (48) In his discussion of Malcolm Little(X) as hipster and hustler, Kelley again reveals a creative understanding of resistance. The exploitation of women, he explains, enabled Malcolm "to resist wage labor, pursue leisure, and demystify the work ethic myth."'(176) By juxtaposing the simultaneously liberating and exploitative qualities of the oppositional culture that Malcolm participated in during the 1940s, Kelley highlights the hipster's creative use of available resources for dissent as well as the profound limits of that dissent.

Kelley also avoids adopting a all-encompassing or romantic definition of resistance. Some critics of subaltern studies have complained that virtually any working class behavior can and has been construed as resistance; an overly inclusive definition of resistance risks precluding any rigorous assessment of either the significance or effectiveness of subaltern resistance. Kelley, to his great credit, is interested in forms of dissent that cannot easily be dismissed. While sensitive to the continuum of black resistance that extended from strategies of veiled dissent to formal radical politics, Kelley is obviously most interested in overt challenges to oppression. For instance, the furtive traditions of protest that Kelley reveals in the first three essays bear directly upon the forms of protest that emerged during the Civil Rights movement. As he explains in Chapter 4, "Birmingham's Untouchables," during the marches in Birmingham in 1963, the people of city's "slums and segregated pool halls resisted injustice and oppression on their own 
terms."(89) They took to the streets, destroyed shop windows, overturned cars, looted, and attacked policemen. The crises of 1963 provided an opening to vent accumulated frustrations using both familiar and new tactics of resistance, tactics which were not always acceptable to the movement's leadership or its white allies. The point is that although Birmingham's "untouchables" may not have been at the bargaining table in 1963, their periodic outbursts entered into the calculus of compromise that brought the Birmingham crisis to a close.

Kelley's careful approach to black resistance informs his equally nuanced understanding of the far-reaching potential of black radicalism. When read in conjunction with Hammer and Hoe, Kelley's first book, Race Rebels is a compelling argument about the central contribution radicals have made to the attack on American racism and inequality. ${ }^{4}$ Kelley implicitly cautions us against exaggerating the contributions of liberals, including white southern liberals, to the struggle for black equality. While the number of black radicals may have been small and the leadership of the Communist Party may have been compromised by all manner of intrigues, Kelley insists that the radical milieu offered blacks creative opportunities for expressions of radical culture that were inconceivable almost anywhere else in American society, including even within liberal circles. These radical cultural expressions in turn informed black political radicalism, prompting, for example, more than a hundred black men to join the Abraham Lincoln Brigade and to fight in the Spanish Civil War. Among the ranks of the Lincoln Brigade or within the Communist Party, at least a few blacks gave voice to some of the most potent and visionary expressions of racial politics in the twentieth century.

So rich and provocative are these essays that they beg for further elaboration and research. Even when Kelley strains against the boundaries of current scholarship he displays an uncanny eye for

4 Robin D. G. Kelley, Hammer and Hoe: Alabama Communists during the Great Depression (Chapel Hill 1990). 
fresh questions and topics. His all-too-brief discussion of black leisure workers, for instance, should be the catalyst for at least few Ph.D. dissertations. As noted earlier, Kelley concedes the exploitation that defined prostitution and companionship. But he also suggests that "sexual play" and dancing were "potentially empowering" since they turn "labors not associated with wage work ... into income." Given his later discussion of the misogyny of black hustlers, the potential of the sex trade to empower black women seems highly speculative. More important, the centrality of coercion and degrading violence in the sexual marketplace would seem to preclude the likelihood that prostitutes experienced much "female pleasure" on the streets on in the clubs.(49) In this instance, I believe Kelley strains to make his argument. At some point, "progressive" cultural politics give way to destructive behavior, which, as Malcolm X insisted, is often a manifestation of internalized oppression.

Kelley's essays also should stimulate new research into the relationship between cultures of resistance and popular music. Historians of oppressed peoples and the labor movement often have incorporated discussions of protest music into their work, but sometimes their analyses seem perfunctory. ${ }^{5}$ Kelley's confident treatment of music, whether be-bop or rap, manifests his deep interest in and appreciation of its power. He notes, for instance, the musical revolution - the emergence of be-bop - that coincided with the era of the zoot suiters. Certainly the subculture of beboppers and of zoot suiters shared intriguing similarities, especially what Francis Davies calls the "black rage" of bop. But the big band tradition, extending from the Kansas City bands to Cab Calloway and Duke Ellington and which nurtured both Coleman Hawkins and Louis Jordan, also promoted an aesthetic that complimented that of the urban hipster. Indeed, recent work on the most adventur-

5 For exceptions, see Robbie Lieberman, "My Song is My Weapon": People's Songs, American Communism, and the Politics of Culture, 1930-1950 (Urbana 1989); and Lipsitz, Rainbow at Midnight, esp. Chapter 13. 
ous swing music emphasizes its emancipatory qualities and counter cultural tendencies. ${ }^{6}$ My point is not to quibble about Malcolm Little's listening habits, or those of his fellow zoot suiters, but rather to caution against limiting the sources of their inspiration to the most obvious and articulate expressions of cultural militancy. Only after we know much more about the musical revolution underway during the late 1930s and 1940s will we be able to understand the cultural landscape that both the zoot suiters and the beboppers occupied.

Taken as a whole, Kelley's essays warn against formulaic interpretative conceits, facile romanticization of the downtrodden, and reductionist depictions of African American culture. What emerges from this approach is a humane and moving portrait of the struggle for survival and a measure of dignity by that huge swath of people at the bottom of the American economic pyramid. Race Rebels speaks directly to the contemporary context when previously sheltered classes of Americans experience gnawing economic insecurity and disruptive work transformations (e. g., corporate downsizing and technological innovation), when multinational corporations appear poised to attain virtual autonomy, when the compensatory state is being dismantled, when the labor movement is effectively moribund, and when urban America is quarantined. Perhaps more and more Americans will learn what the folks "way, way, way below," as Kelley describes them, have understood seemingly forever - even seemingly hegemonic power can be challenged and changed by the people it has marginalized.

I am grateful to Michael $K$. Honey for his comments and suggestions on this review.

6 For example, Burton W. Peretti, The Creation of Jazz: Music, Race, and Culture in Urban America (Urbana 1992). 